\title{
Effects of Miana (Coleus scutellariodes (L) Benth) to Expression of mRNA IL-37 in Balb/c Mice Infected Candida albicans
}

\author{
Marni Karo ${ }^{1}$, Mochammad Hatta ${ }^{2 *}$, WaOde Salma ${ }^{3}$, Ilhamjaya Patellongi ${ }^{4}$, Rosdiana Natzir ${ }^{5}$
}

\begin{abstract}
Marni Karo', Mochammad Hatta ${ }^{2 *}$, WaOde Salma ${ }^{3}$, Ilhamjaya Patellongi ${ }^{4}$, Rosdiana Natzir ${ }^{5}$

'Midwifey Program of Medistra Health Higher School, Jakarta. Indonesia andSchool of Post Graduate Faculty of Medicine, Hasanuddin University, Makassar, INDONESIA.

${ }^{2}$ Molecular Biology and Immunology Laboratory for Infection Diseases, Faculty of Medicine, Hasanuddin University, Makassar, INDONESIA. ${ }^{3}$ Department Nutrition, Faculty of Medicine, Halu Oleo University, Kendari, INDONESIA.

${ }^{4}$ Department of Biostatistic, Faculty of Medicine, Hasanuddin University, Makassar, INDONESIA.

${ }^{5}$ Department of Biochemistry Faculty of Medicine, Hasanuddin University, Makassar, INDONESIA.
\end{abstract}

\section{Correspondence}

\section{Mochammad Hatta}

Department of Medical Microbiology Molecular Biology and Immunology, Laboratory for Infectious Diseases, Hasanuddin University, JI Perintis Kemerdekaan Km 10 Tamalanrea, Makassar 90245, South Sulawesi, INDONESIA.

Phone no: 062411586971

E-mail: hattaram@yahoo.com

History

- Submission Date: 15-06-2017:

- Review completed: 21-07-2017;

- Accepted Date: 27-07-2017

DOI : 10.5530/pj.2018.1.3

Article Available online

http://www.phcogj.com/v10/i1

Copyright

(C) 2018 Phcog.Net. This is an openaccess article distributed under the terms of the Creative Commons Attribution 4.0 International license.

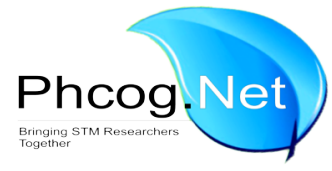

\begin{abstract}
Background: Miana (Coleus scutellariodes (L) Benth) are a herbal medicine with potential anti-inflammatory properties in patients infected with vulvovaginal candidiasis. The objective of this work was to the analyze IL-37 expression following administration of miana leaf extract (MLE) in an animal model of vulvovaginal candidiasis. Material and Methods: Adult Balb/c mice, aged 8-12 weeks and weighing 30-40 g, were divided into five groups. Four groups were administered Candida albicans via intravaginal inoculation with a diluted dose of $10^{-2}$ / $\mathrm{ml}$ and were treated with either MLE, a placebo, or ketoconazole; one group constituted the healthy control and was only treated with MLE. Real-time PCR was used to measure the expression of IL-37. Results: These findings indicated that a component within MLE may mediate its anti-inflammatory characteristics, as indicated by the increase in mRNA IL-37 expression in mice inoculated with C. albicans. The highest increase in fungal load to 101.6 CFU was observed in the placebo group at day 14 . Whereas for the mice treated with MLE at $750 \mathrm{mg} / \mathrm{kg} \mathrm{b.w}$, the fungal load only increased to $30.0 \mathrm{CFU}$, similar to that of mice treated with ketoconazole (29.6 CFU). In the mice treated with MLE at $500 \mathrm{mg} / \mathrm{kg} \mathrm{b.w}$, the fungal load increased to 68.2 CFU. Conclusion: Fungiostatic effect of MLE $750 \mathrm{mg} / \mathrm{kg} \mathrm{BB}$ is not less than ketoconazole and MLE may act as anti-inflammatory throught its role as an antioxidant so it could potentially be used as an alternative treatment in humans especially patients with vulvovaginal candidiasis.
\end{abstract}

Key words: Miana, Vulvovaginal Candidiasis, Interleukin-37 mRNA, Realtime PCR, CFU.

\section{INTRODUCTION}

Miana leaves (Coleus scutellariodes [L] Benth) are a herbal medicine and at the molecular level exhibit anti-inflammatory properties in patients infected with vulvovaginal candidiasis caused by Candida albicans. The importance of herbal medicines in the treatment of vulvovaginal candidiasis has previously been reported.

C. albicans is a fungus that constitutes part of the normal human microbiome but in certain circumstances can cause systemic candidiasis infections. ${ }^{2}$ That may be life threatening. ${ }^{3}$ The mechanisms involved in the spread of C. albicans infection are not fully understood, and the classification of antifungal medicines is incomplete. $^{4,5}$ The increasing number of C. albicans strains that are resistant to the azole class of antibiotics is a challenge in the treatment of candidiasis. ${ }^{6}$ In addition, the use of certain antibiotics, such as derivatives of imidazole, nystatin, amphotericin, and ketoconazole, can cause side effects such as nausea and dizziness. $^{7}$ In many developing countries, especially Indonesia, people believe that alternative treatments using natural materials such as miana leaves can be effective in the treatment of diseases caused by fungi or bacteria.

In vitro research has been show to exhibit anti oxidative, anti-inflammatory and anti alergi activitasin mammalian system. An ample amount of work has been reported on micro propagation of different Coleus spp. From different plant like shoot tips, leaf segment, nodal and intermodal segments. ${ }^{8}$ Immunostimulant therapy with MLE, which is thought to possess anti-inflammatory properties, is the latest approach in alternative medicine to treat vulvovaginal candidiasis infection without any known side effects. This is a promising approach considering that the disease remains prevalent in Indonesia.

It has recently been reported that the cytokine interleukin-37 (IL-37) is an immune mediator with anti-inflammatory activity. ${ }^{9}$ And this cytokine IL-1 derivative has been identified as a natural inhibitor of the non-specific immune system..$^{10}$ The mechanism of action of cytokine IL-37 remains elusive but its pro-inflammatory properties have been reported to be induced in transgenic mice in response to lipo-

Cite this article: Karo M, Hatta M, Salma W, Patellongi I, Natzir R. Effects of Miana (Coleus Scutellariodes [L] Benth) to Expression of mRNA IL-37 in Balb/c Mice Infected Candida albicans. Pharmacog J. 2018;10(1):16-9. 
polysaccharide. ${ }^{11}$ In this study, the relationship between MLE and IL-37 gene expression is examined in a mouse model of vulvovaginal candidiasis infection.

\section{MATERIAL AND METHODS}

\section{Miana leaf extraction}

Miana leaves were obtained from the Research Institute for Spices and Medicinal Plants (Balai Penelitian Tanaman Rempah and Obat (BALITRO), Bogor, Indonesia). The leaves were subjected to an extraction process using ethanol as the solvent in accordance with a method reported. ${ }^{12}$ The MLE obtained was used at doses of 500 and $750 \mathrm{mg} / \mathrm{kg}$ b.w.

\section{Experimental animals and immune response test observations}

Balb/c mice (aged 8-12 weeks, weighing 30-40 grams; $n=25$ ) were maintained in the Molecular Biology and Immunology Laboratory, Microbiology Department Faculty of Medicine, Hasanuddin University (Makassar, Indonesia). The mice were acclimatized for 8 days, then divided into five groups $(n=5)$. Four of the groups were intravaginally inoculated with C. albicans ATCC $10231\left(10^{-2} / \mathrm{ml}\right)$ and were designated: CVM500 (candidiasis vulvovaginal group with an MLE dose of $500 \mathrm{mg}$ / kg b.w), CVM750 (candidiasis vulvovaginal group with an MLE dose of $750 \mathrm{mg} / \mathrm{kg}$ b.w), CV Placebo (candidiasis vulvovaginal group with $0.2 \mathrm{~mL}$ of oral normal saline through a cannula), CVC200 (candidiasis vulvovaginal group with a cetoconazole dose of $200 \mathrm{mg} / \mathrm{kg} \mathrm{b.w}$ ); the other group, M500, was not inoculated with C. albicans and constituted the healthy control group, receiving an MLE dose of $500 \mathrm{mg} / \mathrm{kg}$ b.w. Immune test responses were observed in the mice over 14 days. MLE was orally administered through a cannula. Blood sampling was performed through a submaxillary vein five times in all groups, on day zero before transvaginal C. albicans inoculation (S0), and on days 2, 3, 5, and 14.

\section{Fungi load examination}

The fungal load was examined by taking a vaginal swab, diluting, and then culturing in a cup for 2, 3, 5, and 14 days. After culturing the number of colonies were counted.

\section{RNA extraction and quantitative real-time PCR}

Total mRNA was isolated from blood samples using standard methods and was then kept at $-80^{\circ} \mathrm{C}$ before quantitative real-time RT-PCR using a commercial kit (Applied Biosystems) according to the manufacturer's instructions. Primers used for amplification of the IL-37 gene were forward: 5'-CAGCCTCTGCGGAGAAAGGAAGT-3', andreverse:5' GTTTCTCCTT CTTCAGCTGAAGGGATGGAT-3', GAPDH forward: 5'-ATGAGTATGCCTGCCGTGTG-3', and GAPDH reverse: 5'-CCAAATGCGGCATCTTCAAAC-3'. Expression of the GAPDH gene was analyzed as a control. ${ }^{9}$ All PCRs were repeated three times and the data were analyzed using the instrument detection system Mx4000 and the comparative threshold cycle method. A standard curve was constructed (Applied Biosystems) and indicated good amplification efficiency $(90 \%-100 \%)$.

\section{Statistical analysis}

Data are expressed as the mean \pm SE. To assess differences in IL-37mRNA expression between groups the ANOVA test was employed using the SPSS 23 software. Statistical significance was considered as $p<0.05$.

\section{Ethics statement}

This study was approved by the Health Medical Research Ethics Committee at the Faculty of Medicine, Hasanuddin University (Makassar, Indonesia) with registration number UH16010010, 11 March 2016.

\section{RESULTS}

Our results showed that Balb/c mice inoculated with C. albicans and an MLE dose of $750 \mathrm{mg} / \mathrm{kg}$ b.w. (CVM750) had significantly increased IL-37 mRNA expression $(p>0.05)$ compared with those treated with $500 \mathrm{mg} / \mathrm{kg}$ b.w. MLE (CVM500) after 14 days of treatment; the placebo group showed no significant increase (Figure 1). The healthy control mice (M500) showed no alterations in IL-37 mRNA expression, despitean MLE dose of $500 \mathrm{mg} / \mathrm{kg}$ b.w. interestingly, the increase in mRNA IL-37 expression in the CVM750 group was similar to that observed in mice treated with ketoconazole (CVC200). These findings indicated that a component within MLE may mediate its anti-inflammatory characteristics, as indicated by the increase in mRNA IL-37expression in mice inoculated with C. albicans.

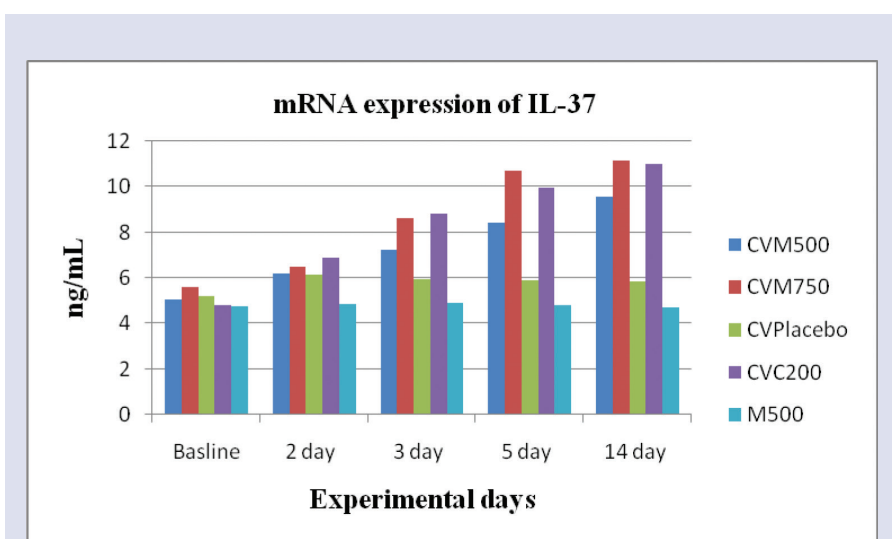

Figure 1: IL-37 mRNA expression in the five groups of Balb/c mice. One-way ANOVA revealed no significant differences in IL-37 mRNA expression between the treatment groups on day 0 (baseline) $(p=0.234)$ but significant differences were detected on days $2,3,5$, and $14(p=0.001)$.

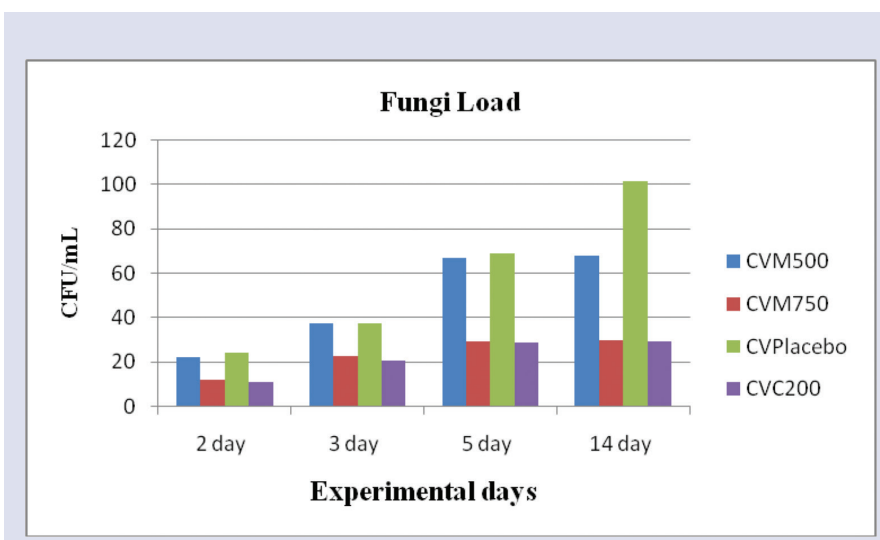

Figure 2: Fungal load in the five groups of Balb/c mice. The mean fungal load in all of the treatment groups induced by $C$. albicans showed a significant difference $(p=0.001)$ between days $2,3,5$, and 14 . 
The highest increase in fungal load to 101.6 CFU was observed in the placebo group at day 14 . Whereas for the mice treated with MLE at $750 \mathrm{mg} / \mathrm{kg}$ b.w, the fungal load only increased to $30.0 \mathrm{CFU}$, similar to that of mice treated with ketoconazole (29.6 CFU). In the mice treated with MLE at $500 \mathrm{mg} / \mathrm{kg}$ b.w, the fungal load increased to $68.2 \mathrm{CFU}$ (Figure 2).

\section{DISCUSSION}

C. albicans is a major cause of vulvovaginitis, which is associated with the loss of acidity in the female genital area. ${ }^{13}$ The main source of this fungus is the normal flora in the human body and infection is often linked to immunosuppression..$^{14}$ In immunosuppressed patients, an increased incidence of fungal species can lead to fungemia. ${ }^{15}$ To provide an optimal and efficient immune response, the body requires antioxidants to prevent and eliminate pathogen invasion. ${ }^{16}$ Antioxidants such as flavonoids contained within MLE have been reported to increase the number of CD4+ T-cells and IFN- $\gamma$ levels, and decrease the number of Mycobacterium tuberculosis colonies in the infected lungs of Wistar mice. ${ }^{12}$ A natural substance containing flavonoids has the potential to inhibit the production of prostaglandin, a pro-inflammatory signaling molecule. ${ }^{17}$

The findings of our study provided evidence that MLE intervention at a dose of $750 \mathrm{mg} / \mathrm{kg}$ b.w. can inhibit the increase in fungal load following challenge with $C$. albicans, indicating that MLE may be exerting anti-fungal activity. The high fungal load (101.6 CFU) on day 14 in the placebo group indicated that following $C$. albicans challenge, mice not treated with MLE failed to control the infection.

Immunostimulanttherapy with MLE may therefore offer a promising alternative to antibiotics for the treatment of vulvovaginalcandidiasis infection without any known side effects. Our findings indicated that treatment with MLE at a dose of $750 \mathrm{mg} / \mathrm{kg}$ b.w. significantly increased IL-37mRNA expression in the mouse model of candidiasis vulvovaginalis (Figure 1), similar to treatment with ketoconazole $200 \mathrm{mg} / \mathrm{kg}$ b.w. Conversely, the placebo group showed no increase in the IL-37mRNA expression level. It is therefore likely that MLE contains an anti-inflammatory component that induces IL-37mRNA expression in mice.

The mechanism of action of IL-37 remains to be fully elucidated but IL-37 expression has been shown to suppress pro-inflammatory cytokines in experimental animals. ${ }^{11}$ And exert anti-inflammatory activities. ${ }^{18}$ IL-37 is cytogenetically located on chromosome 2 q13 and its encoded protein comprises 192 amino acids. ${ }^{19}$ IL-37 is also thought to play a role in dendritic cell regulation, coordinating with the immune response to form a new antigen. ${ }^{20}$ IL-37 expression in the tissues of patients with inflammatory and autoimmune diseases was reported and one study showed that the anti-inflammatory active components (triptolide and triptonide) regulated by IL-37 most likely operated via the ERK1/2 pathway and p38 MAPK activation. ${ }^{21}$ IL-37 expression in macrophages and epithelial cells inhibited pro-inflammatory cytokine synthesis, and hence suppressed inflammation and immunity in various diseases. ${ }^{22}$ Increased production of IL-37 by macrophages and spleen cells was reported to significantly reduce the production of TNF- $\alpha$ during inflammation in mice affected by colitis. ${ }^{22}$ The consistent increase in IL-37 in spleen cells correlated with the increase in production of anti-inflammatory cytokine IL-10 when exposed to the Candida fungus. ${ }^{23}$

\section{CONCLUSION}

MLE (at a dose of $750 \mathrm{mg} / \mathrm{kg}$ b.w.) significantly increased IL-37 mRNA expression and inhibited the increase in fungal load in the mouse model of candidiasis vulvovaginalis. The anti-inflammatory properties of MLE indicate that this herbal medicine could be a promising alternative therapy to the use of antibiotics for patients infected with vulvovaginal candidiasis.

\section{ACKNOWLEDGEMENT}

We would like to thank Rommy Usman and Mus (Molecular Biology and Immunology Laboratory for Infection Diseases, Faculty of Medicine, Hasanuddin University, Makassar, Indonesia), and Ibu Cia (Bio Pharmacy Laboratory, Faculty of Pharmacy Hasanuddin University, Makassar, Indonesia) who helped in the implementation of our research activities. This research was financially supported by the Ministry of Research and Technology, Indonesia.

\section{CONFLICTS OF INTEREST}

The authors declare no conflicts of interest.

\section{ABBREVIATION USED}

MLE: Miana leaf extract; mRNA : Messenger RNA; IL37: Interleukin 37; RT PCR : Realtime PCR; CFU: Colony forming units.

\section{REFERENCES}

1. Karo M, Salma WO, Kamelia E, Bintang M, Hatta M. Determination of OD Value and CFU Dilution for Modeling the Infection of Vulvovaginal Candidiasis on Experimental Mice. Int J Sci Basic Appl Reseach. 28:233-42.

2. Mayer FL, Wilson D, Hube B. Candida albicans pathogenicity mechanisms. Virulence. 2013;4(2):119-28.

3. Polke M, Hube B, Jacobsen ID. Candida survival strategies. Adv Appl Microbiol. 2015;91:139-235. doi:10.1016/bs.aambs.2014.12.002

4. Rubinsztein DC. The roles of intracellular protein-degradation pathways in neurodegeneration. Nature. 2006;443(7113):780.

5. Dhamgaye S, Devaux F, Vandeputte P, Khandelwal NK, Sanglard D, Mukhopadhyay $\mathrm{G}$, et al. Molecular mechanisms of action of herbal antifungal alkaloid berberine, in Candida albicans. PloS one. 2014;9(8):e104554.

6. Matsumoto S, Kurakado S, Shiokama T, Ando Y, Aoki N, Cho O, Sugita T, 2014. In vitro Synergistic Effects of Anthracycline Antitumor Agents and. J. Dev. Drugs 3, 1000125. doi:10.4172/2329-6631.1000125

7. Alka J, Padma K, Chitra J. Antifungal activity of flavonoids of Sida acuta Burm f. against Candida albicans. International Journal of Drug Development and Research. 2012.;4(3):92-6.

8. Nagpal A, Singh B, Sharma S, Rani G, Virk GS. Coleus spp.: Micropropagation and in vitro production of secondary metabolites. Medicinal and Aromatic Plant Science and Biotechnology. 2008;2(1):1-7.

9. Ballak DB, Van Diepen JA, Moschen AR, Jansen HJ, Hijmans A, Groenhof GJ, et al. IL-37 protects against obesity-induced inflammation and insulin resistance. Nature communications. 2014;5:4711.

10. Ye L, Ji L, Wen Z, Zhou Y, Hu D, Li Y, et al. IL-37 inhibits the production of inflammatory cytokines in peripheral blood mononuclear cells of patients with systemic lupus erythematosus: its correlation with disease activity. Journal of translational medicine. 2014;12(1):69.

11. Nold MF, Nold-Petry CA, Zepp JA, Palmer BE, Bufler P, Dinarello CA. IL-37 is a fundamental inhibitor of innate immunity. Nature immunology. 2010;11(11):101422.

12. Pakadang SR, Wahjuni CU, Notobroto HB, Winarni D, Dwiyanti R, Sabir M Hatta M. Immunomodulator Potential of Miana Leaves (Coleus scutellarioides (L) Benth) in Prevention of Tuberculosis Infection. American Journal of Microbiological Research. 2015;3(4):129-34.

13. Cassone A. Vulvovaginal Candida albicans infections: pathogenesis, immunity and vaccine prospects. BJOG: An International Journal of Obstetrics \& Gynaecology. 2015;122(6):785-94.

14. Kwok SC, Schelenz S, Wang X, Steverding D. In vitro effect of DNA topoisomerase inhibitors on Candida albicans. Medical mycology. 2010;48(1):155-60.

15. Estrada-Barraza D, Martínez AD, Flores-Padilla L, Mendoza-De Elias R, SánchezVargas LO. Comparación entre métodos convencionales, ChromAgar Candida $₫$ y el método de la PCR para la identificación de especies de Candida en aislamientos clínicos. Revista Iberoamericana de Micologia. 2011;28(1):36-42.

16. Sordillo LM, Contreras GA, Aitken SL. Metabolic factors affecting the inflammatory response of periparturient dairy cows. Animal Health Research Reviews. 2009; 10(1):53-63.

17. Kumar S, Pandey AK. Chemistry and biological activities of flavonoids: an overview. The Scientific World Journal. 2013.

18. Kumar S, McDonnell PC, Lehr R, Tierney L, Tzimas MN, Griswold DE, et al. Identification and initial characterization of four novel members of the interleu- 
kin-1 family. Journal of Biological Chemistry. 2000;275(14):10308-14.

19. Luo Y, Cai X, Liu S, Wang S, Nold-Petry CA, Nold MF, et al. Suppression of antigen-specific adaptive immunity by IL-37 via induction of tolerogenic dendritic cells. Proceedings of the National Academy of Sciences. 2014;111(42):1517883.

20. He L, Liang Z, Zhao F, Peng L, Chen Z. Modulation of IL-37 expression by triptolide and triptonide in THP-1 cells. Cellular and Molecular Immunology. 2015; 12(4):515-18.

21. Duddukuri GR, Rao YV, Rao DN, Athota RR. Immunomodulation of ovalbuminspecific IgG and other classes of antibody response by honey in mice. Indian
Journal of Clinical Biochemistry. 2001;16(1):89.

22. McNamee EN, Masterson JC, Jedlicka P, McManus M, Grenz A, Collins CB, Nold MF, Nold-Petry C, Bufler P, Dinarello CA, Rivera-Nieves J. Interleukin 37 expression protects mice from colitis. Proceedings of the National Academy of Sciences. 2011;108(40):16711-6.

23. Van de Veerdonk F.L, Gresnigt M.S, Oosting, M, van der Meer J.W.M, Leo L.A, Netea M.G, et al. Protective host defense against disseminated candidiasis is impaired in mice expressing human interleukin-37. Front. Microbiol. 6. doi:10.3389/fmicb.2014.00762

\section{GRAPHICAL ABSTRACT}

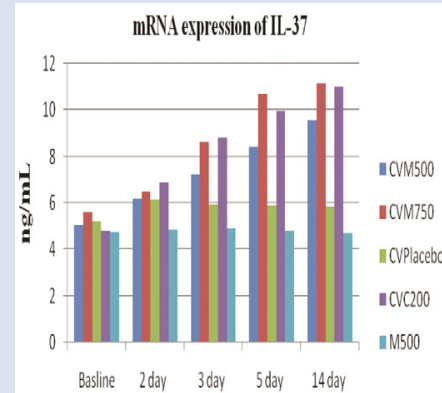

Experimental days

ICYM500
ICYM750
ICYPlacebo
ICVC200
IM500$$
10
$$

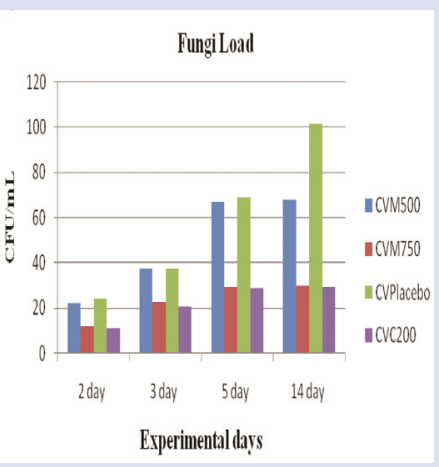

\section{SUMMARY}

- MLE (at a dose of $750 \mathrm{mg} / \mathrm{kg}$ b.w.) significantly increased IL-37 mRNA expression and inhibited the increase in fungal load in the mouse model of candidiasis vulvovaginalis. The anti-inflammatory properties of MLE indicate that this herbal medicine could be a promising alternative therapy to the use of antibiotics for patients infected with vulvovaginal candidiasis.

\section{ABOUT AUTHORS}

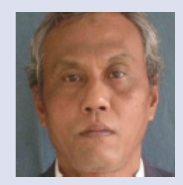

Prof. Mochammad Hatta, MD, PhD, Clin Microbiologist (Cons) is a professor on Molecular Biology and Immunology for Infectious Diseases from Medical Faculty of Hasanuddin University, Makassar, Indonesia

Cite this article: Karo M, Hatta M, Salma W, Patellongi I, Natzir R. Effects of Miana (Coleus scutellariodes (L) Benth) to Expression of mRNA IL-37 in Balb/c Mice Infected Candida albicans. Pharmacog J. 2018;10(1):16-9. 